\title{
Integrated Geophysical and Geological Mapping of the Lithological and Geological Structures at a Proposed Generator Site
}

\author{
Akwasi Acheampong Aning*, Vandycke Sarpong Asare, David Dotse Wemegah, \\ Reginald Mensah Noye, Kwasi Preko, Sylvester Kojo Danuor
}

Department of Physics, Kwame Nkrumah University of Science and Technology, Kumasi, Ghana

Email: *acheamponganing@gmail.com

How to cite this paper: Aning, A. A., Asare, V. S., Wemegah, D. D., Noye, R. M., Preko, K., \& Danuor, S. K. (2019). Integrated Geophysical and Geological Mapping of the Lithological and Geological Structures at a Proposed Generator Site. Journal of Geoscience and Environment Protection, 7, 73-85.

https://doi.org/10.4236/gep.2019.712005

Received: August 31, 2019

Accepted: December 14, 2019

Published: December 17, 2019

Copyright $\odot 2019$ by author(s) and Scientific Research Publishing Inc. This work is licensed under the Creative Commons Attribution International License (CC BY 4.0).

http://creativecommons.org/licenses/by/4.0/

\begin{abstract}
The discovery of oil in commercial quantity in Ghana has led to increase in infrastructural development to provide the needed services to the oil industry. The siting of these industries requires the characterization of the subsurface to determine its suitability to host these facilities. It is in this line that seismic refraction and geo-electrical surveys were conducted on a site near Takoradi, Ghana that has been planned to host a generator and its appurtenances for the oil industry. The objective of the survey was to provide subsurface information critical for the design of earthing system for the proposed generator plant and its appurtenances. The ABEM SAS4000 Terrameter with the Lund imaging system and a 24-channel ABEM Terraloc MK6 were respectively used for the electrical and seismic refraction data collection. The seismic refraction and resistivity results identify three lithological units namely, dry gravel, sand and silty clay layer, water saturated sand and silty clay layer and granodiorites basement rocks. The first layer has a thickness of $10 \mathrm{~m}$ and the second layer with thickness in the range of 5 to $10 \mathrm{~m}$. The lithological classifications as obtained from these results correlate with the drill logs. Electrical grounding will be suitable at a depth of $10 \mathrm{~m}$ beneath resistivity profile two at a distance between 32 to $52 \mathrm{~m}$.
\end{abstract}

\section{Keywords}

Electrical Resistivity Tomography, Seismic Refraction, Borehole, Subsurface, Mapping

\section{Introduction}

The discovery of significant crude oil in Ghana in 2007 and the subsequent pro- 
duction in 2010, has brought a tremendous increase in infrastructure development especially in and around the Sekondi-Takoradi Municipality. These facilities are used as servicing centres for the oil industry as well as homes for the people working in the oil industry. In order to maintain the integrity of these structures, there is the need for detailed geological knowledge of the subsurface for geotechnical site characterization purposes, especially for the siting of a generator plant, which is the object of study. This knowledge can be acquired by the application of geophysical methods. The use of geophysical techniques continue to increase from the conventional usage of exploring for natural resources into civil engineering, rock mechanics, disaster prevention, environmental preservation, archaeology, impact cratering science among others because of the geological model that is generated from the geophysical data (Takahashi et al., 2006; Knödel et al., 2007).

Integrated geophysical and geological methods have played significant roles in exploring for natural resources, environmental issues and geotechnical investigations.

Electrical resistivity distribution within the subsurface is mapped by injecting current into the ground and measuring the resulting potential differences. Conventionally, this is done either by profiling where the lateral variation of electrical resistivity is measured or vertical electrical sounding (VES) which investigates vertical variation of resistivity. Recently, electrical resistivity tomography (ERT) technique which combines profiling and VES has become the preferred choice for near surface investigations.

For the ERT, a single injection of electrical current can result in multiple potential difference measurements thereby reducing drastically the time spent on the field. ERT has been widely used in engineering, environmental and shallow surface investigations (van Schoor, 2002; Aning et al., 2014; Andrews et al., 2013; Ugwu \& Ezema, 2013; Obasi et al., 2015; Binley et al., 2015). The electrical resistivity method has also been used in mining and abandoned mining areas (Martinez-Pagan et al., 2013; Martinez-Lopez et al., 2013) and limestone or dolomite dominant zones which are susceptible to cavity formation due to natural processes (van Schoor, 2002; Metwaly \& AlFouzan, 2013) to study the subsurface before projects were embarked on. Subsurface cavities have also been surveyed to assess the likelihood of landslides in an area with the ERT (Panek et al., 2010). Additionally, the ERT technique has found usage in road construction (Farooq et al., 2012), site characterization for borehole development (Ogungbe et al., 2010) and the detection of groundwater pollution (Uchegbulam \& Ayolabi, 2014; Wemegah et al., 2017). Other studies also confirm its ability to map shallow anomalies (Kumar, 2012; Nero et al., 2016) and geological units (faults, fractures and quartzite veins) related to the formation of groundwater systems (Mendoza \& Dahlin, 2008). In Ghana, Aning et al. (2013a, 2013b) used it to map the subsurface resistivity structure of the Bosumtwi impact crater.

Soil resistivity (conductivity) is one of the several influencing factors of soil corrosiveness. Soil corrosivity determines where and how industrial generating plants grounding grids should be designed. Thus, knowledge of in-situ soil electrical 
resistivity (the exact inverse of conductivity) can provide a qualitative indicator of the corrosion potential for underground structures. The soil resistivity will inform how much surface area of grounding wire must be in contact with soil to give a low enough contact resistance for safe grounding of equipment in power plants or substations. For soil corrosion potential, Rajan \& Venugopalan (1977), classified soils according to resistivity values as in Table 1 .

Low resistivity soils have very high corrosion effect and the same time provide effective grounding.

Seismic refraction uses seismic signal that returns to the surface after refraction at the boundaries of subsurface layers with different seismic velocities. Seismic refraction uses this change of direction to obtain some subsurface information. Seismic wave velocity is the most fundamental parameter in seismic methods and it relates to the elastic properties and in addition, mineral content, porosity, lithology, saturation of pore fluid and the degree of compaction. Geophysicists and geotechnical engineers use the seismic refraction method to obtain information about the subsurface geology, particularly the depth to bedrock, rippability and unconsolidated overburden (Milsom \& Eriksen, 2013). There are several types of seismic refraction methods depending on the objectives, but the commonest one is the use of first arrivals of p-waves. The refraction method is appropriate in situations where p-wave velocity increases with depth (Knödel et al., 2007; Gadallah \& Fisher, 2008). Seismic refraction also provides valuable velocity information for the interpretation of reflection surveys such as saturated aquifer thickness and weathered fault zones. Seismic refraction surveys are useful in delineating the velocity distribution within the subsurface. In 2016, Addai et al. (2016) carried out a seismic refraction survey at KNUST, Kumasi, Ghana and reported p-wave velocity of $4.3 \mathrm{~km} / \mathrm{s}$ for granite.

Interpretation of geophysical results is enhanced with borehole data and it helps in understanding the conditions of the site because boreholes produce direct subsurface structure information below the ground surface. Borehole measurements give information about the geology of the area for example: lithology, porosity and permeability, presence and orientation of fractures, determination of dip and strike of strata, water quality among others, thus, providing detailed information about the subsurface physical properties. The results from neighbouring boreholes can be correlated to generate cross-section of the site (Knödel et al., 2007; Milsom \& Eriksen, 2013; Reynolds, 2011).

Table 1. Soil resistivity classification (Rajan \& Venugopalan, 1977).

\begin{tabular}{cc}
\hline Resistivity range & \\
\hline$(\Omega \mathrm{m})$ & Corrosivity \\
\hline $0-10$ & Verysevere \\
$10.01-20$ & Severe \\
$20.01-50$ & Moderate \\
$50.01-100$ & Mild \\
$100+$ & Very mild \\
\hline
\end{tabular}


The objective of this study was to determine the seismic and resistivity parameters, and consequently determine the depth to bedrock and other major structural features critical for siting of the generator plant. The study area is basically a virgin area as far as subsurface geophysical investigations are concerned. The results will therefore serve as a baseline for further studies in other areas of similar geology.

\section{Project Site Description}

The research area is located in the Sekondi-Takoradi metropolis of Ghana, which is situated between latitudes $40^{\circ} 52^{\prime} 30^{\prime \prime} \mathrm{N}$ and $50^{\circ} 04^{\prime} 00^{\prime \prime} \mathrm{N}$ and longitudes $1037^{\circ} 00^{\prime \prime} \mathrm{W}$ and $1052^{\circ} 30^{\prime \prime} \mathrm{W}$. The area is within the southwestern part of equatorial zone of Ghana and is $242 \mathrm{~km}$ west of Accra, the capital town. The metropolis is bounded to the north by the Mpohor-Wassa District, to the south by the Gulf of Guinea, to the west by the Ahanta West District, and to the east by Shama District (Figure 1). It has fairly uniform temperature, ranging between $220^{\circ} \mathrm{C}$ in August and $300^{\circ} \mathrm{C}$ in March. The metropolis has a bimodal raining season. The major season runs from April to June and the minor season from September to the end of November with a mean annual rainfall of $2350 \mathrm{~mm}$. Relative humidity is generally high throughout the year between $50 \%$ and $70 \%$ in the dry season and $75 \%$ and $85 \%$ in the wet season. The topography is undulating with the central parts of Takoradi lying at an altitude of six meters below the mean sea level. These lowlying areas are interspersed with ridges and hills that range from 30 to $60 \mathrm{~m}$ above sea level. Vegetation is highly woodland in the northern and central parts, whilst thicket is intermingled with tall grass species along the coast, especially in areas where there are no permanent crops (Fei-Baffoe et al., 2014).

Geologically, the area falls within the sedimentary basin granitoids which form part of the extensive Eburnean Granitoid plutons that intruded the Early Proterozoic Birimian Supergroup in Ghana (Hirdes et al., 1988, 1992; Taylor et al., 1992). These granitoids suites in Ghana are characterized into four main groups namely the sedimentary basin granitoid; belt granitoids; and the late post Eburnean, K-rich granitoid and the Winneba granitoids (Hirdes et al., 1988; Leube et al., 1990). The sedimentary basin granitoids within which the study area falls, is a large granitoid batholiths emplaced within the Birimian metasediments. This granitoid coincides with the central axes of the sedimentary basins (Leube et al., 1990). It has wide range of rocks that include quartz, diorite, tonalite to trondhjemite compositional types as well as adamellite and granites. These rocks are characterized by weak foliations. The main ferromagnesian mineral is biotite, which is commonly accompanied by muscovite (Leube et al., 1990). Geochronological analysis done using $\mathrm{U} / \mathrm{Pb}$ zircon and monazite dating by Hirdes et al. (1992) on this granitoids plutons gives it an age of $2116 \pm 2 \mathrm{Ma}$.

\section{Data Acquisition and Processing}

\subsection{Data Acquisition}

Field measurements were conducted using the 24 channel ABEM Terraloc Mk6 


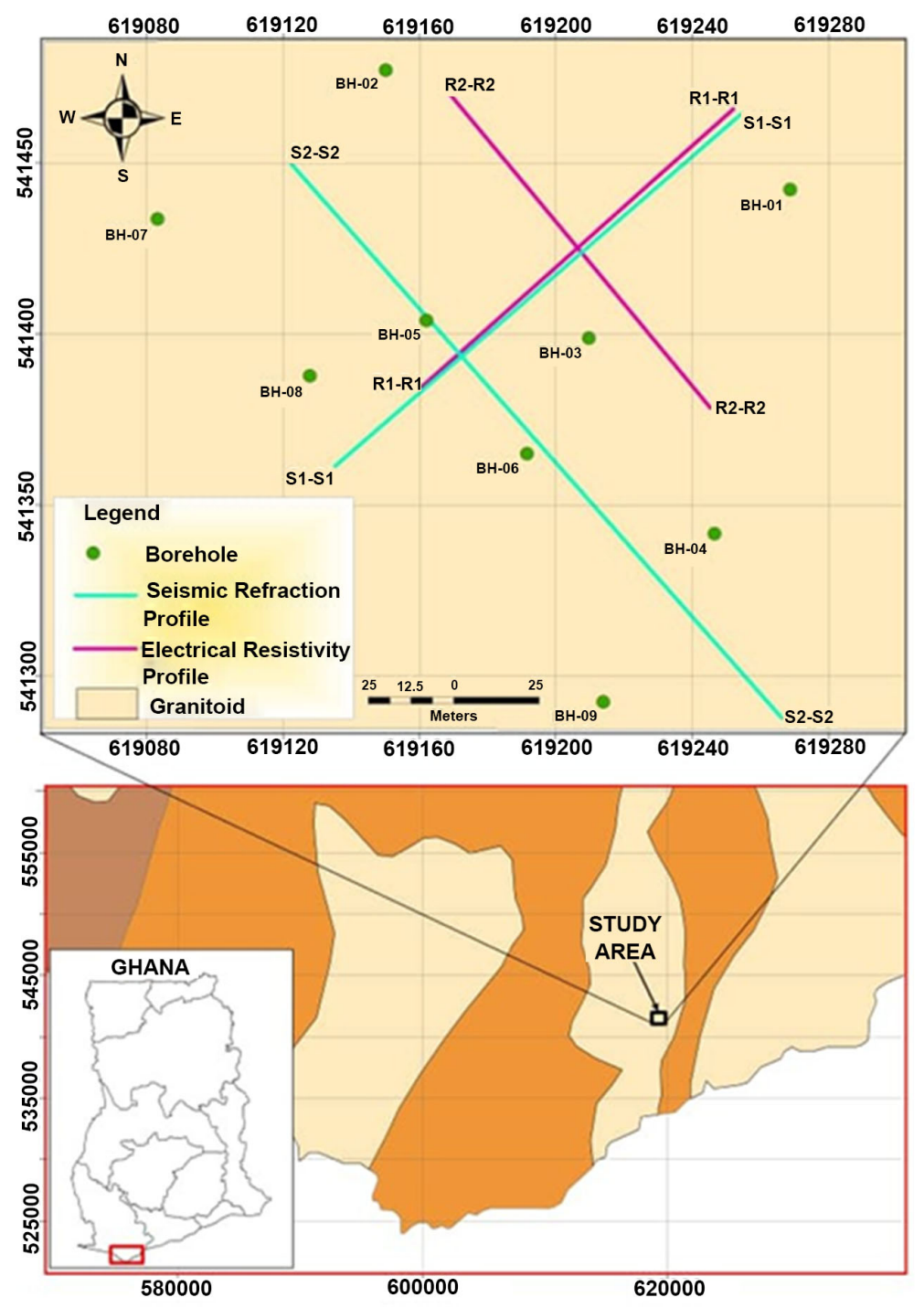

Figure 1. Geological map of the area showing the seismic lines in green and resistivity lines in violet.

and Abem LUND imaging system to take the seismic refraction and apparent resistivity measurements respectively. The electrical resistivity tomography (ERT) technique was employed for the resistivity data collection. Two (2) profiles were surveyed using the gradient array with a minimum electrode separation of $2 \mathrm{~m}$. The Grad4L8 and Grad4S8 protocols of this type of array were made use of. The Grad4L8 is the long layout protocol whilst the Grad4S8 is the short layout protocol and is designed to supplement the former for the shortest electrode spacings only. In all, two $120 \mathrm{~m}$ long orthogonal traverse lines $\mathrm{R}_{1}-\mathrm{R}_{1}$ and $\mathrm{R}_{2}-\mathrm{R}_{2}$ were surveyed.

The seismic refraction survey was conducted using $5 \mathrm{~m}$ geophone spacing. Investigations were carried out on two profiles namely $S_{1}-S_{1}$ (profile 1 ) and $S_{2}-S_{2}$ (profile 2). The profile $S_{1}-S_{1}$ was $155 \mathrm{~m}$ and $S_{2}-S_{2}$ was $240 \mathrm{~m}$ in length. Shot points along profile 1 were located at $0,20,47.5,77.5,135$ and $155 \mathrm{~m}$. Shot 
points for the first spread along profile 2 were located at 27.5, 50, 102.5, 115 and $135 \mathrm{~m}$. The shot points for the second spread along profile 2 were $105,132.5$, $162.5,192.5,220$ and $240 \mathrm{~m}$.

Nine boreholes were drilled and logged across the site with depth ranging between the minimum of $9.7 \mathrm{~m}$ for hole 1 to a maximum of $22.2 \mathrm{~m}$ for hole 6 .

\subsection{Data Processing}

The resistivity data was processed using the Res2DInv software. Bad datum points were first eliminated from the data, after which it was inverted using the Gauss-Newton least squares inversion based on the robust inversion routine. 2D models were obtained in the process and displayed using the 'user defined logarithmic contour intervals'. This step results in even contour values and spacing on the resistivity models for all the profiles for easy comparison. Topographical correction was not done because the surface was scooped and levelled.

The processing of the seismic data was done using ReflexW software version 7.2. All picked travel times were put together and the wave front inversion was used for the layer reconstruction. The travel time curves of the single shots for each profile were put together and assigned layer velocities. No static correction was done because the seismic lines were on a flat surface and limited filtering was done. The p-wave velocities of the acoustic layers and depths were done using the intercept time method.

The drill logs were generated with Goldensoftware Strater. The depth and lithology logs were created one after the other using the interval lithology information that was obtained during the logging of the hole.

\section{Results and Discussion}

\subsection{Results}

\subsubsection{Resistivity}

Figure 2 shows electrical resistivity tomographies for profiles 1 and 2. Figure 2 (a) depicts three distinct resistivity zones. The top layer with high resistivity $>$ $460 \Omega \mathrm{m}$ was observed from the surface to a depth of about $10 \mathrm{~m}$. The thickness of this layer varies between 5 and $10 \mathrm{~m}$ at various sections of the image. A thickness of $5 \mathrm{~m}$ was recorded at the point of intersection of the two orthogonal lines $R_{1}-R_{1}$ and $R_{2}-R_{2}$. This region comprises of sandy clay and clayey gravels. A low resistivity zone with values ranging between 60 to $200 \Omega \mathrm{m}$ occurs at a depth of 8 $\mathrm{m}$ from the 24 to $64 \mathrm{~m}$ distance points. This second layer represents wet sandy and silty clays. A moderately low resistivity zone between 200 and $280 \Omega \mathrm{m}$ occurs at a depth below $8 \mathrm{~m}$ and from the $64 \mathrm{~m}$ distance point to the end of the profile. This zone represents silty clays.

The electrical resistivity tomography models for the second profile is shown in Figure 2(b). Similar to Figure 2(a), this image (Figure 2(b)) produced three distinct resistivity zones. The top high resistivity layer with resistivity $>460 \Omega \mathrm{m}$ from the surface to a depth of about $8 \mathrm{~m}$ has varying thickness between 5 and 10 

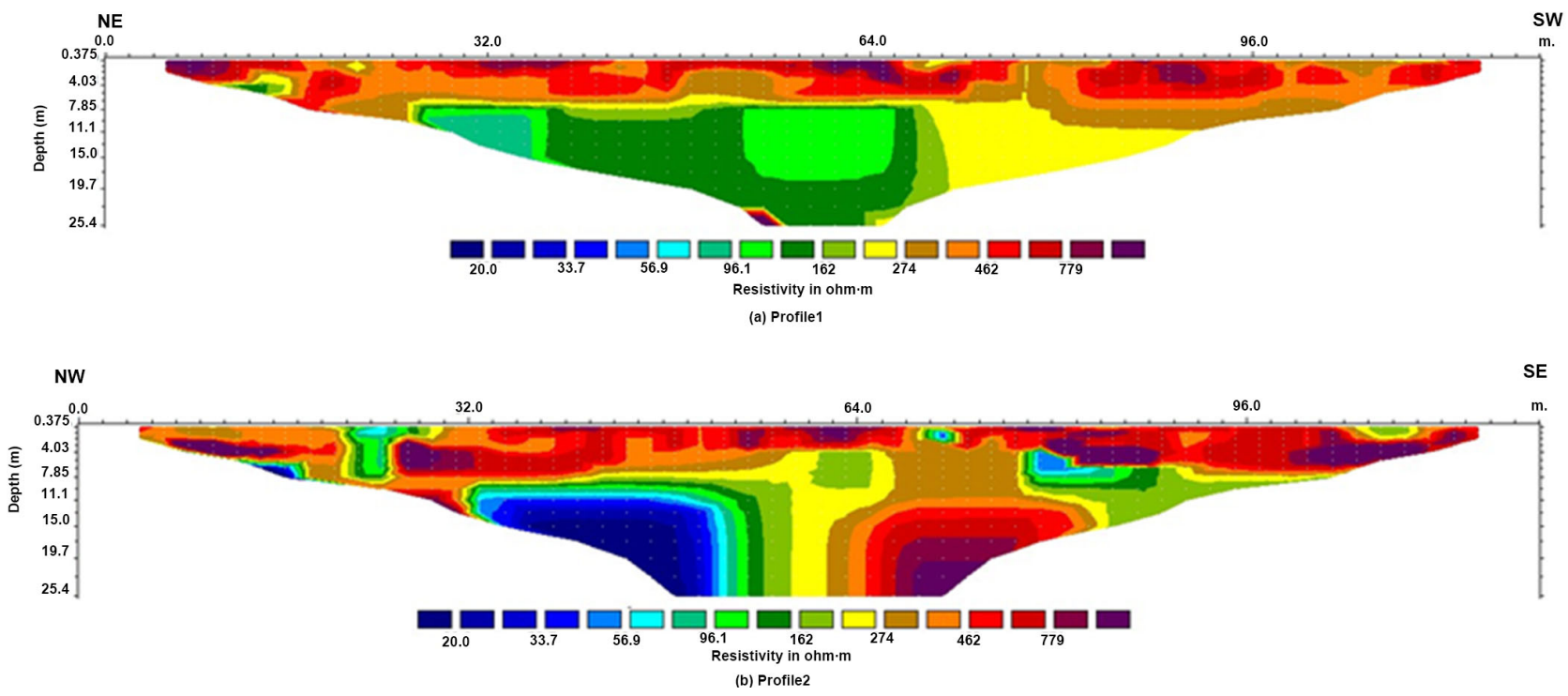

Figure 2. 2D electrical resistivity models for profiles 1 and 2.

$\mathrm{m}$. The topmost layer is made up of sandy clay and clayey gravels. The high resistivity zone at the bottom right corner of the model with resistivity values > $460 \Omega \mathrm{m}$ represents the weathered basement granodiorites. A major very low resistivity zone (Figure 2(b)) $<50 \Omega \mathrm{m}$ below a depth of $10 \mathrm{~m}$ between 32 and 52 $\mathrm{m}$ distance points could be a saturated silty clay or burried river channel.

\subsubsection{Seismic Refraction}

Figure 3(a) and Figure 3(b) are the seismic refraction models of lines $S_{1}-S_{1}$ and $\mathrm{S}_{2}-\mathrm{S}_{2}$ respectively. It exhibits a three-layer model with undulating interfaces. The topmost layer has a thickness averaging about $10 \mathrm{~m}$ and p-wave velocity of $<2$ $\mathrm{kms}^{-1}$. This layer is made up of the dry silty clay, sandy clay and clayey gravels. The second layer has a velocity between $2.00-4.70 \mathrm{kms}^{-1}$ and average thickness of about 10 and $5 \mathrm{~m}$ for profile 1 (Figure 3(a)) and profile 2 (Figure 3(b)) respectively. The second layer of profile 1 (Figure $3(\mathrm{a})$ ) thickens at the centre and shrinks towards the end. The layer consists of mainly of saturated sandy and silty clays. Beneath it is the last layer with velocity $>4.70 \mathrm{kms}^{-1}$. This layer comprises the basement granodiorites.

\subsubsection{Drilling}

The depths and lithologies of the nine boreholes showing the various units are given in schematic form in Figure 4 and Figure 5. Clayey sand was found only in hole 2 with a thickness of about $1 \mathrm{~m}$ and was located within the topmost $1 \mathrm{~m}$ in the northeastern side of the survey area. Clayey gravels were found in four holes: 1, 4, 6 and 9 (Figure 4 and Figure 5). Hole 1 has the thickest clayey gravel layer with a combined thickness of about $2 \mathrm{~m}$ with a $2 \mathrm{~m}$ thick sandy clay sandwiched between them followed by holes 4, 9 and 6 in that order. Silty clays were not found in holes 1,2 and 3 (Figure 4 and Figure 5) which are situated in the north and northeastern portion of the area. Silty clay is the dominant lithology 


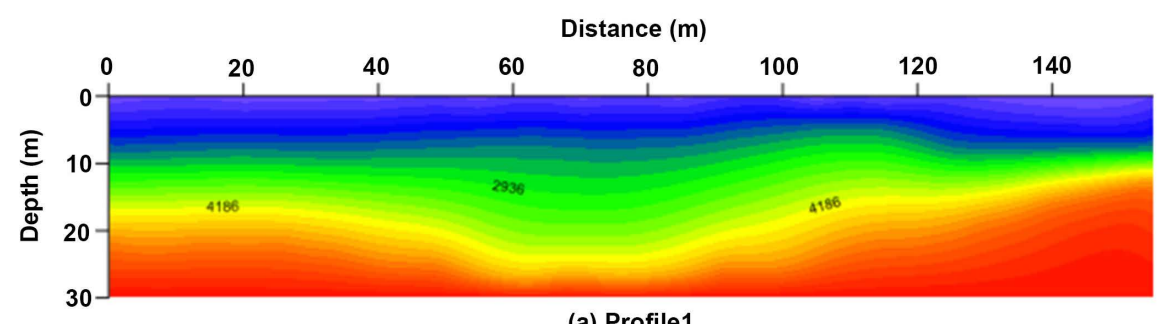

(a) Profile1

Distance $(m)$

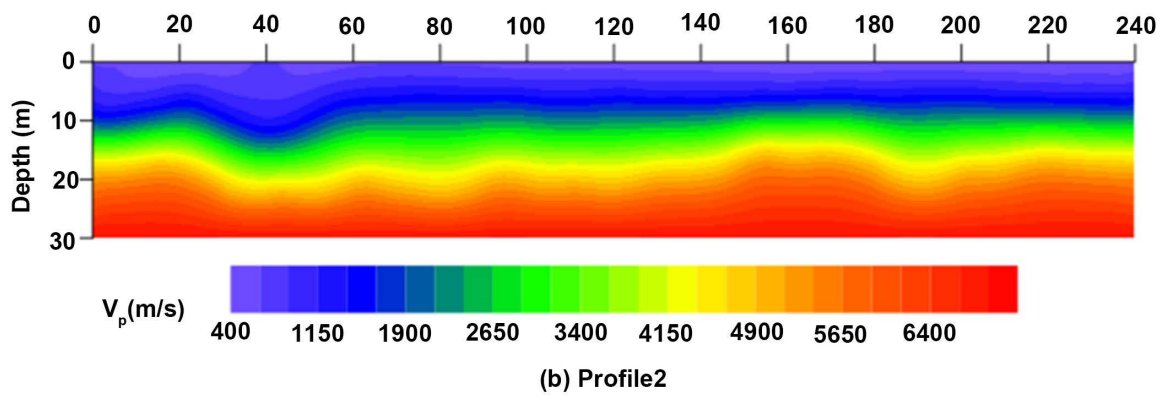

Figure 3. 2D velocity models for the seismic profiles.

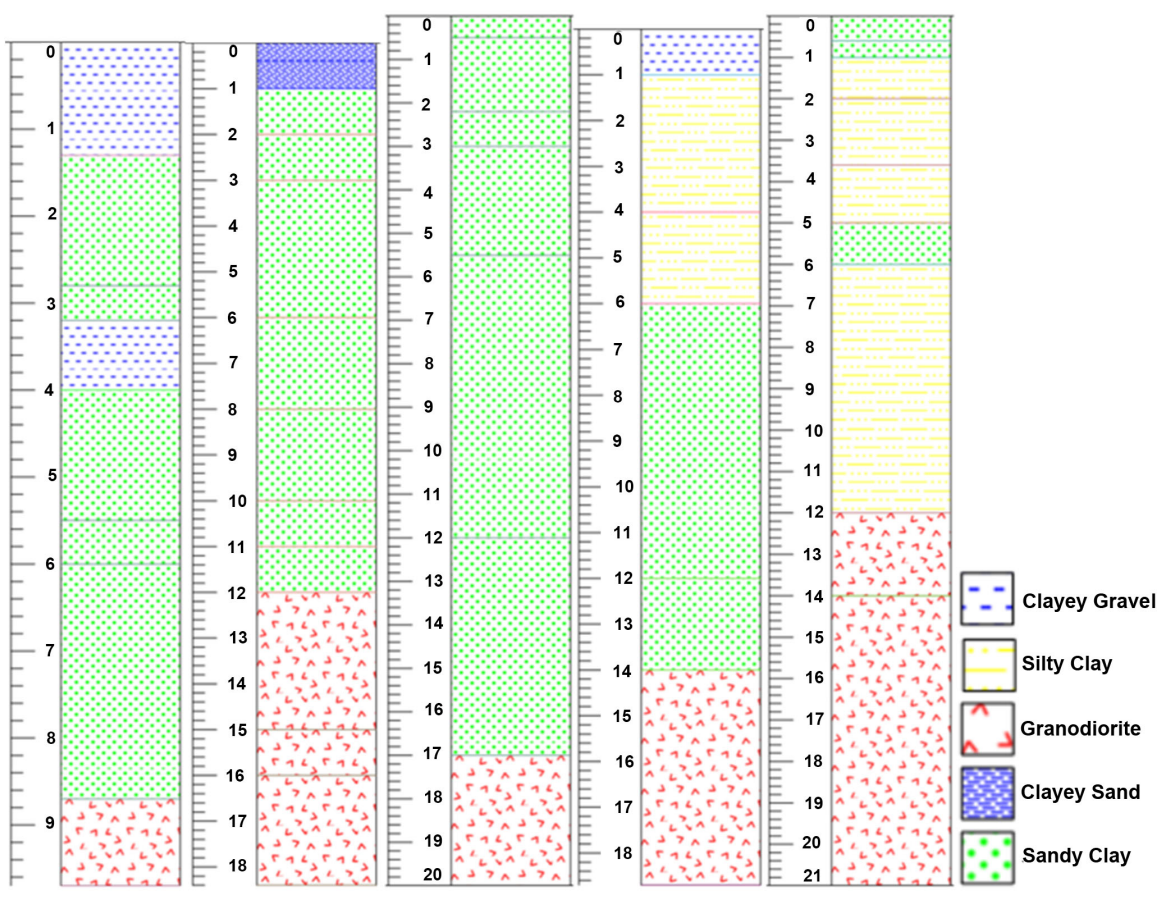

Figure 4. Depth and lithology logs for boreholes 1 to 5.

in hole 6 with a thickness greater than $15 \mathrm{~m}$. The thickness of the silty clay deposit decreases from $15 \mathrm{~m}$ in hole 6 to a combined thickness of $10 \mathrm{~m}$ in hole 5, to 9 $\mathrm{m}$ in hole $9,5 \mathrm{~m}$ in hole 4, $2 \mathrm{~m}$ in hole 8 and $1 \mathrm{~m}$ in hole 7 . Sandy clay and granodiorites were found in all the nine holes. The width of the sandy clay increases from $0.2 \mathrm{~m}$ in hole 9 to $17 \mathrm{~m}$ in hole 3 in the following order: holes $9,6,5,8,7,1$, 4,2 and 3 . The thicknesses of granodiorites of the various holes could not be determined because the drilling did not go beyond it. The topmost granodiorites 

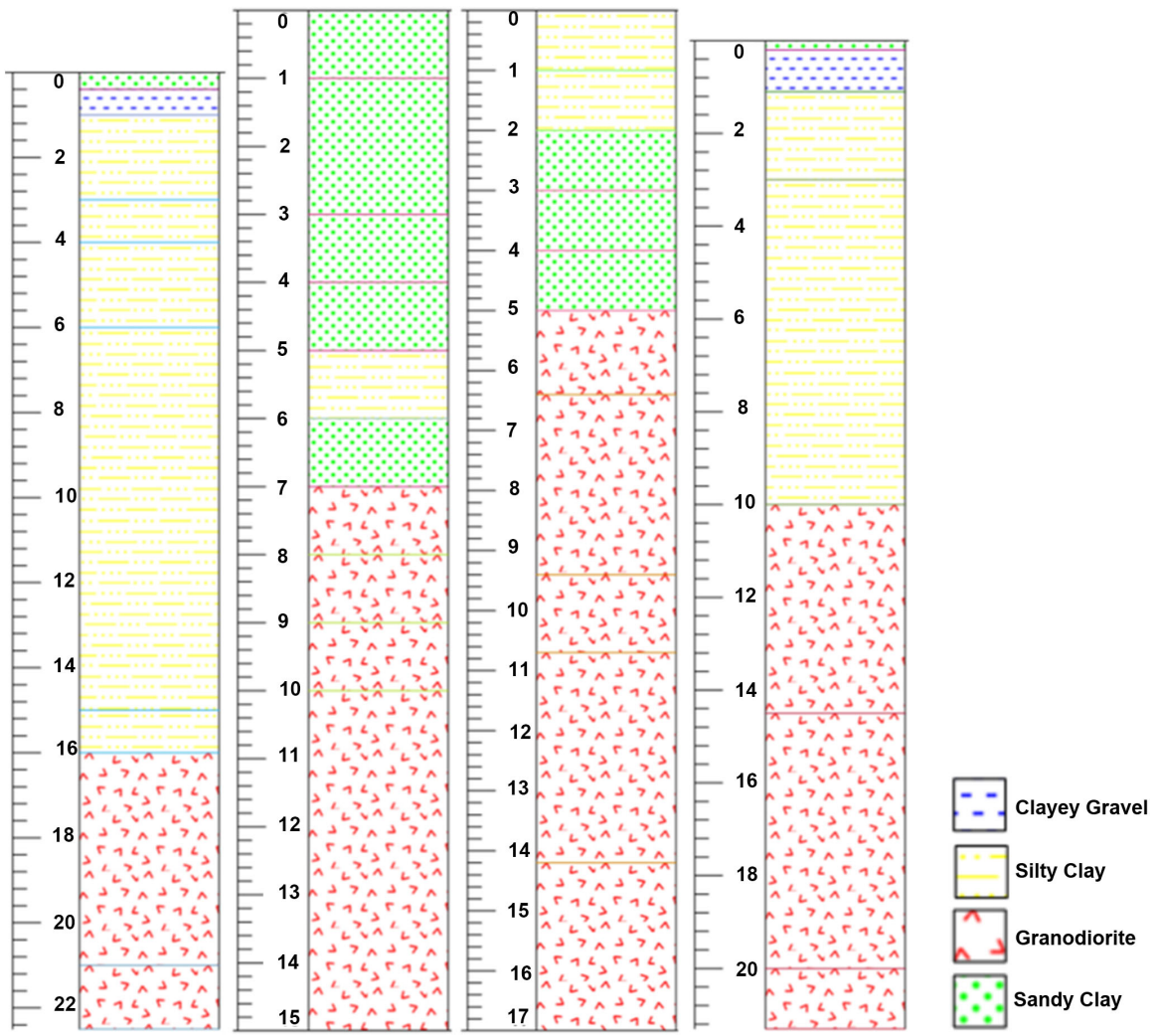

Figure 5. Depth and lithology logs for boreholes 6 to 9 .

were located $5 \mathrm{~m}$ below the surface in hole 8 and the deepest is in hole 3 at a depth of $17 \mathrm{~m}$.

\subsection{Discussion}

Electrical resistivity and seismic velocity depend on whether the subsurface materials are massive or disseminated and wet or dry. The electrical resistivity and seismic velocity within the same formation can differ depending on these factors. The electrical resistivity results compare very well with that of the refraction seismic for the near surface in that they all have a top layer with thickness of about $10 \mathrm{~m}$. This topmost layer which has a moisture content less than the one below has a higher resistivity and a lower seismic velocity. Due to evapotranspiration and seepage, resistivity values near the surface are higher than those deep down within the same formation because the near surface is drier and for seismic waves, the velocity tends to increase with increasing moisture content.

The seismic results correlate very well with the drill logs. Borehole 5 which is at a point distance of $65 \mathrm{~m}$ (Figure 1) on profile 2, the basement granodiorites are at a depth of about $15 \mathrm{~m}$ on the seismic model (Figure $3(\mathrm{~b})$ ) and at $12 \mathrm{~m}$ in borehole 5 (Figure 4). Borehole 6 which is about $2 \mathrm{~m}$ from profile 2 (Figure 1) and at a point distance of $130 \mathrm{~m}$, the granodiorite bedrock is at a depth of about $16 \mathrm{~m}$ on both the seismic profile 2 (Figure $3(\mathrm{~b})$ ) and the drill $\log$ (Figure 5 ). The summary of the various seismic ground properties obtained from the seismic survey are shown in Table 2. 
Table 2. Physical properties of soils/rocks.

\begin{tabular}{cccc}
\hline Item & Layer 1 & Layer 2 & Layer 3 \\
\hline Depth $(\mathrm{m})$ & $0-10$ & $5-25$ & $>20$ \\
Density $\left(\mathrm{kg} / \mathrm{m}^{3}\right)$ & 1800 & 2000 & 2700 \\
$\mathrm{~V}_{\mathrm{p}}(\mathrm{km} / \mathrm{s})$ & $<2.00$ & $2.00-4.70$ & $>4.70$ \\
$\mathrm{~V}_{\mathrm{s}}(\mathrm{km} / \mathrm{s})$ & $<1.15$ & $1.15-2.71$ & $>2.71$ \\
$\mathrm{G}\left(\mathrm{N} / \mathrm{m}^{2}\right)$ & $<2.5$ & $2.5-14.7$ & $>14.7$ \\
$\mathrm{E}\left(\mathrm{N} / \mathrm{m}^{2}\right)$ & $<6.2$ & $6.2-36.8$ & $>36.8$ \\
Poisson Ratio $(v)$ & 0.23 & $0.23-0.25$ & $>0.25$ \\
Rock/Soil type & Sand/gravel/clay & Sandstone & Granite \\
& (water saturated) & & \\
\hline
\end{tabular}

Clayey gravels were found in the drill holes which are on the eastern side (Figure 1) of the study area and it appears that the clayey gravels are probably restricted to that side of the site. Sandy clay is the predominant lithology in the area up to a depth of about $12 \mathrm{~m}$ and having the largest thickness of about $17 \mathrm{~m}$ in hole 3 (Figure 4). The basement rock is made up of the granodiorites sometimes grading from decomposed through completely weathered to very strong and moderately jointed. Boreholes 6 and 9 (Figure 5) have the same sequence of lithology with thin sandy clay and clayey gravel in that order at the top followed by a thick column of silty clay and the basement granodiorites. The composition of various soils and rocks in the project area was estimated as follows: clayey sand: about $0.6 \%$; clayey gravel: $2.4 \%$; silty clay: $26.3 \%$; sandy clay: $31.7 \%$ and the granodiorites: $39 \%$.

Corrosion will be severe below $10 \mathrm{~m}$ on profile 2 (Figure 2(b)) between 32 and $52 \mathrm{~m}$ distance points as a result of the low resistivity. Corrosion will be very mild on the entire profile 1 (Figure 2(a)) because the resistivity beneath this survey line is greater than $50 \Omega \mathrm{m}$. This is based on the resistivity-corrosivity classification of soils as reported by Rajan \& Venugopalan (1977). Grounding for the proposed generator plant will be ideal at a depth of $10 \mathrm{~m}$ between 32 and 52 $\mathrm{m}$ distance points on profile 2 (Figure 2 (b)) due to the low resistivity of this portion of the subsurface (Schaefer, 1955).

\section{Conclusion}

In this study, we conducted electrical resistivity, seismic refraction, as well as drilling in a site earmarked for sitting a generator plant. The results from the Res2DInv resistivity and ReflexW seismic models correlated well with the drill logs. From the models, we were able to delineate low and high resistivity zones which are good sites for grounding and positioning the generator and its accessories respectively. We were able to map the basement granodiorites. It's evident that a single geophysical method is not enough to identify all possible subsurface features at a site and the integrated approach must be adopted. The analysis of 
the electrical resistivity and seismic refraction models together with drilling results have shown that they are effective tools for subsurface characterization and has applicability in other terrains. The procedure adopted in this work can be used to audit existing electrical generators.

\section{Acknowledgements}

We are grateful to the Department of Physics, KNUST for assisting us with the instruments that were used for the data collection. We are also indebted to $\mathrm{Mr}$. Thomas Dwomoh (the geophysics lab technician) for his invaluable support. Every second of his time with us on the field was hugely significant.

\section{Conflicts of Interest}

The authors declare no conflicts of interest regarding the publication of this paper.

\section{References}

Addai, E., Asare, V. S., \& Aning, A. A. (2016). Application of Shallow Seismic Refraction and 2d Electrical Resistivity Imaging to Site Investigations. International Journal of Scientific and Research Publications, 6, 357-368.

Andrews, N. D., Aning, A. A., Danuor, S. K., \& Noye, R. M. (2013). Geophysical Investigations at the Proposed Site of the Knust Teaching Hospital Building Using 2d and 3d Resistivity Imaging Techniques. International Research Journal of Geology and Mining, 3, 113-123.

Aning, A. A., Sackey, N., Jakalia, I. S., Sedoawu, O., Tetteh, E. H., Hinson, G., Akorlie, R. K., Appiah, D., \& Quaye, E. (2014). Electrical Resistivity as a Geophysical Mapping Tool; a Case Study of the New Art Department, Knust-Ghana. International Journal of Scientific and Research Publications, 4, 1-7.

Aning, A. A., Tucholka, P., \& Danuor, S. K. (2013a). 2D Electrical Resistivity Tomography (ERT) Survey Using the Multi-Electrode Gradient Array at the Bosumtwi Impact Crater, Ghana. Journal of Environment and Earth Science, 3, 12-16.

Aning, A. A., Tucholka, P., \& Danuor, S. K. (2013b). The Bosumtwi Meteorite Impact Crater, Ghana: New Results on the Impact Direction of the Meteorite from 2d Electrical Resistivity Tomography (ert) Survey. International Research Journal of Geology and Mining (IRJGM), 3, 147-157.

Binley, A., Hubbard, S. S., Huisman, J. A., Revil, A., Robinson, D. A., Singha, K., \& Slater, L. D. (2015). The Emergence of Hydrogeophysics for Improved Understanding of Subsurface Processes over Multiple Scales. Water Resources Research, 51, 3837-3866. https://doi.org/10.1002/2015WR017016

Farooq, M., Park, S., Song, Y. S., Kim, J. H., Tariq, M., \& Abraham, A. A. (2012). Subsurface Cavity Detection in a Karst Environment Using Electrical Resistivity (ER): A Case Study from Yongweol-ri, South Korea. Earth Sciences Research Journal, 16, 75-82.

Fei-Baffoe, B., Nyankson, E. A., \& Gorkeh-Miah, J. (2014). Municipal Waste Management in Sekondi-Takoradi Metropolis, Ghana. Journal of Waste Management.

Gadallah, M. R., \& Fisher, R. (2008). Exploration Geophysics. Berlin: Springer Science \& Business Media.

Hirdes, W., Davis, D., \& Eisenlohr, B. (1992). Reassessment of Proterozoic Granitoid Ages in Ghana on the Basis of $\mathrm{u} / \mathrm{pb}$ Zircon and Monazite Dating. Precambrian Re- 
search, 56, 89-96. https://doi.org/10.1016/0301-9268(92)90085-3

Hirdes, W., Saager, R., \& Leube, A. (1988). New Structural, Radiometric and Mineralogical Aspects of the Au-Bearing Tarkwaian Group of Ghana. Bicentennial Gold, 88, 146-148.

Knödel, K., Lange, G., \& Voigt, H.-J. (2007). Environmental Geology: Handbook of Field Methods and Case Studies. Berlin: Springer Science \& Business Media. https://doi.org/10.1007/978-3-540-74671-3

Kumar, D. (2012). Efficacy of Electrical Resistivity Tomography Technique in Mapping Shallow Subsurface Anomaly. Journal Geological Society of India, 80, 304-307. https://doi.org/10.1007/s12594-012-0148-2

Leube, A., Hirdes, W., Mauer, R., \& Kesse, G. O. (1990). The Early Proterozoic Birimian Supergroup of Ghana and Some Aspects of Its Associated Gold Mineralization. Precambrian Research, 46, 139-165. https://doi.org/10.1016/0301-9268(90)90070-7

Martinez-Lopez, J., Rey, J., Duenas, J., Hidalgo, C., \& Benavente, J. (2013). Electrical Tomography Applied to the Detection of Subsurface Cavities. Journal of Cave and Karst Studies, 75, 28-37. https://doi.org/10.4311/2011ES0242

Martinez-Pagan, P., Gomez-Ortiz, D., Martin-Crespo, T., Manteca, J., \& Rosique, M. (2013). The Electrical Resistivity Tomography Method in the Detection of Shallow Mining Cavities. A Case Study on the Victoria Cave, Cartagena (SE Spain). Engineering Geology, 156, 1-10. https://doi.org/10.1016/j.enggeo.2013.01.013

Mendoza, J., \& Dahlin, T. (2008). Resistivity Imaging in Steep and Weathered Terrains. Near Surface Geophysics, 6, 105-112. https://doi.org/10.3997/1873-0604.2007036

Metwaly, M., \& AlFouzan, F. (2013). Application of 2-D Geoelectrical Resistivity Tomography for Subsurface Cavity Detection in the Eastern Part of Saudi Arabia. Geoscience Frontiers, 4, 469-476. https://doi.org/10.1016/j.gsf.2012.12.005

Milsom, J., \& Eriksen, A. (2013). Field Geophysics.

Nero, C., Aning, A. A., Danuor, S. K., \& Noye, R. M. (2016). Delineation of Graves Using Electrical Resistivity Tomography. Journal of Applied Geophysics, 126, 138-147. https://doi.org/10.1016/j.jappgeo.2016.01.012

Obasi, I. A., Onwe, I. M., \& Igwe, E. O. (2015). Geoelectrical Subsurface Characterization for Foundation Purposes in the College of Agricultural Sciences (cas) Campus, Ebonyi State University, Abakaliki, Southeastern Nigeria. Journal of Environment and Earth Science, 5, 42-52.

Ogungbe, A. S., Olowofela, J. A., Da-Silva, O. J., Alabi, A. A., \& Onori, E. O. (2010). Subsurface Characterization Using Electrical Resistivity (Dipole-Dipole) Method at Lagos State University (LASU) Foundation School, Badagry. Advances in Applied Science Research, 1, 174-181.

Panek, T., Margielewski, W., Taborik, P., Urban, J., Hradecky, J., \& Szura, C. (2010). Gravitationally Induced Caves and Other Discontinuities Detected by 2D Electrical Resistivity Tomography: Case Studies from the Polish Flysch Carpathians. Geomorphology, 123, 165-180. https://doi.org/10.1016/j.geomorph.2010.07.008

Rajan, S., \& Venugopalan, S. I. (1977). Corrosion and Grounding Systems. IEEE Transactions on Industry Applications, 4, 297-306. https://doi.org/10.1109/TIA.1977.4503411

Reynolds, J. M. (2011). An Introduction to Applied and Environmental Geophysics. Preview, 2011, 33-40. https://doi.org/10.1071/PVv2011n155other

Schaefer, L. (1955). Electrical Grounding Systems and Corrosion. Transactions of the American Institute of Electrical Engineers, Part II: Applications and Industry, 74, 75-83. https://doi.org/10.1109/TAI.1955.6371476 
Takahashi, T., Takeuchi, T., \& Sassa, K. (2006). International Society for Rock Mechanics-Commission on Application of Geophysics to Rock Engineering-Suggested Methods for Borehole Geophysics in Rock Engineering. International Journal of Rock Mechanics and Mining Sciences, 43, 337-368.

https://doi.org/10.1016/j.ijrmms.2005.09.003

Taylor, P., Moorbath, S., Leube, A., \& Hirdes, W. (1992). Early Proterozoic Crustal Evolution in the Birimiam of Ghana: Constraints from Geochronology and Isotope Geochemistry. Precambrian Research, 56, 97-111.

https://doi.org/10.1016/0301-9268(92)90086-4

Uchegbulam, O., \& Ayolabi, E. A. (2014). Application of Electrical Resistivity Imaging in Investigating Ground Water Pollution in Sapele Area, Nigeria. Journal of Water Resource and Protection, 6, 1369-1379. https://doi.org/10.4236/jwarp.2014.614126

Ugwu, G. Z., \& Ezema, P. O. (2013). 2D Electrical Resistivity Imaging for the Investigation of the Subsurface Structures at the Proposed Site for Kauridan Estate at Ibagwa-Nike, Southeastern Nigeria. International Journal of Scientific Research in Knowledge, 1, 528-535. https://doi.org/10.12983/ijsrk-2013-p528-535

van Schoor, M. (2002). Detection of Sinkholes Using 2D Electrical Resistivity Imaging. Journal of Applied Geophysics, 50, 393-399. https://doi.org/10.1016/S0926-9851(02)00166-0

Wemegah, D. D., Fiandaca, G., Auken, E., Menyeh, A., \& Danuor, S. K. (2017). Spectral Time-Domain Induced Polarisation and Magnetic Surveying an Efficient Tool for Characterisation of Solid Waste Deposits in Developing Countries. EAGE, Near Surface Geophysics, 15, 75-84. https://doi.org/10.3997/1873-0604.2016048 